\title{
Disasters in 'development' contexts: Contradictions and options for a preventive approach
}

\begin{tabular}{|c|c|}
\hline \multicolumn{2}{|c|}{$\begin{array}{l}\text { Author: } \\
\text { Kenneth Hewitt }{ }^{1}\end{array}$} \\
\hline \multicolumn{2}{|c|}{$\begin{array}{l}\text { Affiliation: } \\
{ }^{1} \text { Department of Geography } \\
\text { and Environmental Studies, } \\
\text { Cold Regions Research } \\
\text { Centre, Wilfrid Laurier } \\
\text { University, Canada }\end{array}$} \\
\hline \multicolumn{2}{|c|}{$\begin{array}{l}\text { Correspondence to: } \\
\text { Kenneth Hewitt }\end{array}$} \\
\hline \multicolumn{2}{|c|}{$\begin{array}{l}\text { Email: } \\
\text { khewitt@wlu.ca }\end{array}$} \\
\hline \multicolumn{2}{|c|}{$\begin{array}{l}\text { Postal address: } \\
28 \text { Rhodes Ave, Toronto, } \\
\text { Ontario M4L 2Z9, Canada }\end{array}$} \\
\hline \multicolumn{2}{|c|}{$\begin{array}{l}\text { Received: } 18 \text { Mar. } 2013 \\
\text { Accepted: } 25 \text { Mar. } 2013 \\
\text { Published: } 31 \text { May } 2013\end{array}$} \\
\hline \multicolumn{2}{|c|}{$\begin{array}{l}\text { Keywords: } \\
\text { climate change; } \\
\text { development; disasters; } \\
\text { emergency measures; social } \\
\text { vulnerability }\end{array}$} \\
\hline \multicolumn{2}{|c|}{$\begin{array}{l}\text { How to cite this article: } \\
\text { Hewitt, K., 2013, 'Disasters } \\
\text { in "development" contexts: } \\
\text { Contradictions and options } \\
\text { for a preventive approach', } \\
\text { Jàmbá: Journal of Disaster } \\
\text { Risk Studies 5(2), Art. \#91, } \\
8 \text { pages. http://dx.doi. } \\
\text { org/10.4102/jamba.v5i2.91 }\end{array}$} \\
\hline \multicolumn{2}{|c|}{$\begin{array}{l}\text { 1st Biennial Conference, } \\
\text { Southern African Society for } \\
\text { Disaster Reduction (SASDiR), } \\
09 \text { to } 11 \text { October 2012, } \\
\text { Potchefstroom, South Africa }\end{array}$} \\
\hline \multicolumn{2}{|c|}{$\begin{array}{l}\text { Copyright: } \\
\text { (C) 2013. The Authors. } \\
\text { Licensee: AOSIS } \\
\text { OpenJournals. This wor } \\
\text { is licensed under the } \\
\text { Creative Commons } \\
\text { Attribution License. }\end{array}$} \\
\hline \multicolumn{2}{|l|}{ Read online: } \\
\hline 口idn & $\begin{array}{l}\text { Scan this QR } \\
\text { code with your } \\
\text { smart phone or } \\
\text { mobile device } \\
\text { to read online. }\end{array}$ \\
\hline
\end{tabular}

The relations of development and disaster offer a starting point for an overview of disaster risk reduction (DRR) in African contexts. A social vulnerability approach is adopted with its goal of improving conditions for persons and places most at risk. However, this approach faces serious contradictions in both the disasters and development scenes. Disaster events and losses have grown exponentially in recent decades. So have advances in disaster-related knowledge and the institutions and material resources devoted to disaster management. Evidently, the latter have not reduced disaster incidence or over all losses. Similar contradictions appear in development. By some measures, in most developing countries the economy has grown much faster than population. Yet, indebtedness, unemployment and insecurity seem worse in many countries. Poverty, the avowed target, remains huge in urban, peri-urban and rural areas singled out by disaster losses. Problems also arise from separate treatment of development and disaster. Climate change and the global financial crises challenge some of the most basic assumptions. The promise of 'developed nations', built around massive use of fossil fuels, puts global and African economic growth on a collision course with environmental calamity. The 2008 financial crisis has undermined the safety of global majorities, as well as reliance on development assistance. The case for alternatives in development and DRR is reinforced, including the vulnerability-reducing responses highlighted in the Hyogo framework for action. However, this is being undermined by a return to a civil defence-type approach, an increasingly militarised, and for-profit, focus on emergency management.

\section{Introduction}

. The issue of disasters must be an intrinsic component of development schemes ... (Lavell 1994)

Disaster is widely linked to development issues, especially in so-called developing countries (DCs); that is, recipients of external development assistance according to various criteria of need or donor preferences, a category which includes most African countries. The relations of development and disaster are an appropriate place to begin, if from a critical standpoint. This is especially relevant for the social vulnerability approach adopted here and its goal of improving conditions for persons and places most at risk. It requires looking beyond disaster itself to the larger socio-economic order. What happens in pre-emergency and post-emergency conditions assumes primary importance. Improvements in safety appear likely only where economic and social change increase capacities and protections ahead of extreme events. In such terms, disaster cannot be segregated from everyday, on-going conditions and development (Fordham 2003; Wisner et al. 2004). This is to distinguish between the very real trauma and irreplaceable losses experienced by victims and the origins of that experience; between the need for emergency assistance and how crises come about. For DCs, the basic issue is whether or not development decisions have, in fact, taken disaster risks into consideration, have improved or aggravated peoples' vulnerability. Van Niekerk (2008) shows how the historical relations of development and disaster have had an influence on disaster risk reduction (DRR) globally and in terms of major institutional actors. His findings urge caution about the common assumption that this is only about so called under-development. Development programmes themselves often fail to benefit those most at risk and can, in fact, actually increase their vulnerability, or even turn into disasters for them. This is also a challenge, given the still dominant emphasis on agent-specific natural or technological hazards and emergency management, which can divert attention and funding away from long-term safety measures (Gilbert 1998; Hewitt 1983a; United Nations [UN] \& World Bank 2010).

Social scientists have argued the case for focusing on human vulnerability for some time (Enarson \& Morrow 1998; Lavell 1994; O’Keefe, Westgate \& Wisner 1976; Oliver-Smith 1986; White 1969). This argument came of age, perhaps, in the 1994 Yokohama Conference, which marked a shift towards social factors and preventive measures in the international decade for natural disaster reduction (IDNDR). Certainly, there is overuse and misuse of vulnerability notions, particularly 
when made the object, not a symptom of more basic societal conditions. Also, identifying those most at risk only as vulnerable, misses their ingenuity and adaptive capacities, or can hide systemic undermining of those capacities. In too many places where disaster impacts are severe there is repression, exploitation and high levels of criminal activity (Davis 2006; Egbo et al. 2012; Ekine 2013). The emphasis on vulnerability is mainly a question of balance in DRR; that is not to say the need for knowledge and monitoring of environmental dangers, or the demands for emergency assistance, will not continue to be essential too. Nevertheless, only pre-disaster and post-disaster measures can improve safety and reduce disaster risks, improvements that rarely occur without the meaningful involvement of communities at risk.

This present paper examines certain contradictions in the relations of disasters and development and, in doing so, must struggle with some contradictions of its own. On the one hand, this is an occasion of celebration; a memorial to the energy, achievements and continuing presence of Pat Reid in our work. It coincides with the 10-year anniversary of the African Centre for Disaster Studies (ACDS) and served as a keynote address to introduce themes for the 1st Biennial Conference of the Southern African Society for Disaster Reduction in October 2012. The attendance and papers of the conference indicate a very positive atmosphere and level of commitment. On the other hand, being upbeat about my specific task is difficult; namely, to give an overview of the state of DRR and where southern Africa sits within a global perspective. On balance, the disasters scene seems as bad or worse now than at any time in the past 60 years. Some of us believe there are achievements and goals that show things can be turned around. The trend, however, has been mostly in the opposite direction. I happen to agree with the principles and recommendations of the Hyogo framework for action (HFA) (United Nations Office for Disaster Risk Reduction [UNISDR] 2006). There are many local and a few regional programmes keeping in line with, and benefiting from, HFA (Olowu 2010). However, the story for major international, state and corporate actors is disappointing at best. On HFA, lip-service and inaction go along with evident priorities taking us in other directions (Hannigan 2012; United Nations Office of the Special Envoy for Haiti [UNOSE] 2012). Amongst the most worrisome are the implications of global climate change and the global financial crisis, which I return to below as special challenges for development and DRR in African contexts.

This paper mainly considers knowledge and knowledge worker roles, so a few words about 'practice' are in order. As a duty of public care, or, for that matter, private care, I suggest DRR work is only justified in pursuit of better protection for the more vulnerable persons and communities. This is especially so if, as the paper suggests, most losses could be prevented and by widely available and affordable means. On the other hand, professionals spend their time dealing with knowledge issues - data, models and theories, approved standards, protocols, reports, assessments, in teaching and training, meetings and inquiries. For these, notions of disaster and development prefigure, improve, or compromise outcomes. In this regard, it is hard to ignore some persistent contradictions in both the disasters and development fields, whether taken separately or together.

\section{Contradictions regarding disasters}

Worldwide, disasters and the losses experienced in them have been growing for a century or more (UN \& World Bank 2010) (see also the International Disaster Database, http://www.emdat.be/). In wealthier nations, it has been the economic losses that have expanded, not deaths; yet, both have increased in many other countries (World Bank \& Independent Evaluation Group [IEG] 2006). This cannot be attributed to greater geophysical risk. Climate change is affecting the frequency and magnitude of weather-related extremes, but this does not explain their destructiveness. The primary causes are growing concentrations of vulnerable people and property, exposed in dangerous sites and lacking effective protections (Hewitt 2013; United Nations Development Programme [UNDP] 2004). The problem is especially acute in and around rapidly growing urban centres (Fernandez 1999; Pelling 2003a). However, in southern Africa as elsewhere, it is impossible to separate urban risks from impoverishment and unsustainable transformations of ex-urban resource lands, or developments that drive people into the cities (Oliver-Smith \& Hoffman 2003; Penz, Drydyk \& Bose 2011; Satterthwaite 1991).

Differences in national wealth and modernisation can significantly affect safety measures, but very destructive disasters also occur in the wealthiest countries. Recent ones include the outcomes of the 2011 earthquake and tsunami in Japan and floods in Queensland, Australia, the 2010 Christchurch earthquake in New Zealand and the 2005 Hurricane Katrina in the USA. These disasters also highlight unusually vulnerable, disadvantaged people, or developments lacking adequate safety considerations.

In general, disproportionate losses in particular places and groups of people underscore the role of social conditions in disasters. A secular view, at least, sees earthquakes, floods or fire as indiscriminate threats. They do not choose to target particular people. However, losses in disasters do so (UNDP 2004). Impoverishment and pre-existing disadvantage identify the majority of disaster victims, as well as disproportionate losses in sub-groups amongst them. Examples include the exceptional numbers of women killed in communities around the Indian Ocean in the 2004 tsunami and of poorer women and the elderly in the 1995 Kobe, Japan earthquake (Hewitt 2007).

Singular losses sometimes happen as, for example, of school children in schools improperly planned and maintained. Thousands died in school collapses in the 2008 earthquake in Sichuan, China and perhaps as many as 20000 in northern Pakistan in 2005. Professional concern should be engaged 
by reports of established safety standards being ignored or unenforced. It seems most of the lethal building collapses in those schools and also in the earthquakes at Izmit, Turkey in 1999 and Bhuj, India in 2001, could have been prevented if national standards and building codes had been enforced (Ozerdem \& Jacoby 2006; World Bank 2001).

The upward spiral of disasters and losses is widely reported; however, less often reported is the parallel growth in ostensibly countervailing measures. There have been great improvements in relevant scientific and technical knowledge and an exponential rise in public and private expenditures relating to disaster risks. Institutions responsible for public safety and security expanded dramatically from the late 1970s and 1980s, leading to the IDNDR of the 1990s, initially directed at geophysical disasters in DCs. For various reasons, the IDNDR never fulfilled its promise. Nevertheless, much-expanded capabilities were put in place through UN organisations and strategies such as the UNDP, ISDR, DRR and the HFA, by the International Federation of Red Cross and Red Crescent Societies (IFRCRCS) and by the African Union's New Partnership for African Development, et cetera. The proliferation of international conferences and regional centres testify to this, as do the numbers of professional and research journals covering this subject area. Arguably, there are groups, sectors and places that are safer, or engage in potentially risky activities with more remarkable safety records, than at any other time. This runs in parallel to the reduced toll of illness and increased longevity observed in better-off countries and groups.

Calhoun (2004), referring just to the 'management of emergencies', describes this as:

a very big business and a very big part of what multilateral agencies and NGOs do ... [serving to] mobilize tens of thousands of paid workers and volunteers through the United Nations, multilateral organizations, bilateral aid agencies, and NGOs. (p. 236)

In part, this shows how strongly 'the emergency' shapes awareness and decisions throughout our field, often merged with national security and other areas of crisis management. In such terms, Hannigan (2012:22) sees a broad 'global policy field' of natural disasters. He too finds it 'becoming considerably more crowded and turbulent ... [with] the influx of thousands of new NGOs into emergency and disaster operations in Africa and Central America ...'. And he notes further expansion - and confusion - as DRR becomes entwined with climate change adaptation (cf. Food and Agricultural Organization of the United Nations [FAO] 2008; World Bank 2012).

In recent decades, growth has also been observed in the commitments of financial institutions (UN \& World Bank 2010), with the reinsurance industry being notable in its actual and potential roles (Kunreuther \& Michel-Kerjan 2010; Swiss Re 2012). The development banks have assumed a large presence in disasters and the World Bank appears to have the largest, funding some 528 projects between 1984 and 2006, including 89 post-disaster reconstruction loans. The largest group of recipients was in sub-Saharan Africa, with 128 projects (World Bank \& IEG 2006:12-14). For the least wealthy countries, special terms are offered by an affiliate, the International Finance Corporation. The Asian Development Bank (ADB) is another major player with '560 disaster management projects' between 1987 and 2012 (ADB 2013). Others include the Development Bank of Southern Africa. These, as well as bilateral donors and major charitable organisations, have vastly increased the scope and scale of international financing relating to all phases of disaster risk.

Other relevant growth areas are of note. The work of disasters scholars such as Gilbert White came from recognising connections between resource conservation and natural hazards. These scholars quickly found common cause with biosphere concerns and what would become known as 'sustainable development'. The International Biological Program was associated with an upsurge of environmental anxieties, magnified by its successor the Man and Biosphere Program. A critical initiative was the 1972 Stockholm Conference on the Human Environment, culminating in the Brundtland report (World Commission on Environment and Development 1987). In due course, various disaster-focused institutions highlighted relations of disaster to poverty, disease and malnutrition, enforced migrations, urbanisation and growth of mega-cities, environmental degradation and unsustainable practices, conflict and insecurity (Baez \& Santos 2008; Bankoff, Frerks \& Hihorst 2004; IFRCRCS 2004; Mitchel 1999; UNDP 2004; UNISDR 2002). The national and global institutions involved have greatly expanded.

Nevertheless, the disasters grow too and improvements on the ground become harder to discern. No one expects a turnaround in a year, or even a decade. Yet, suppose the year of the Rio Conference in 1992 is taken as a baseline? That event drew together and sought common cause for the already substantial communities concerned with ecological health, sustainability and disaster reduction. It was followed by the expansion of institutional involvement outlined above. Nevertheless, many endangered species, ecosystems and indigenous cultures are in worse shape now than in 1992, as is sustainability in general. In the same time span, some 1.3 million people have died in disasters and 4.4 billion been adversely affected. Damages are estimated at $\$ 3.3$ trillion (UNISDR 2012). Evidently too, the last decade was worse than the previous one! Much-expanded information, institutional capacities and resources have not prevented the increase in overall environmental degradation or disaster losses.

\section{Contradictions regarding development}

Development presents a parallel dichotomy of apparent great progress and conspicuous failure. On the one hand, in DCs, some key indicators of economic and social development have increased much faster than the population. Material 
productivity, if measured by GDP, resource extraction, value of exports and imports, has grown exponentially. Consumption has soared in terms of per capita purchases and ownership of such modern goods as motor vehicles, TVs, computers and cell phones. Infrastructure and services have sped ahead in terms such as numbers of vaccinations, length of roads, telecom use, schooling, or women's literacy rates.

Although less often mentioned in relation to development, some other areas involve conspicuous growth, including military spending, whether on arms or by regular and irregular forces. Foreign commercial land acquisitions have also surged, reportedly exceeding 47 million ha in subSaharan Africa in 2008-2009 alone (GRAIN 2012). Perhaps the most phenomenal growth can be seen in illicit financial flows, wealth coming mainly from development and not as easily hidden today (Global Financial Integrity [GFI] 2008). In 2006, estimates for African countries ranged from $\$ 850$ billion to $\$ 1.3$ trillion, increasing at a rate of $18.2 \%$ per year and mainly flowing to banks in developed countries (Egbo et al. 2012; GFI 2012). Of course, these are development 'gains' but they hardly fit the national cost-benefit model (Kern 2010). They are being siphoned off and out of the countries as stolen assets, capital flight and tax evasion strategies. Overly optimistic or pessimistic forecasts are also disputed by more specific conditions, notably whom, and which sectors, benefit from development (Karuri-Sebina et al. 2012; UN 2011).

On the other hand, there are more familiar negative elements which it is sufficient to simply list here (see Table 1). National and broad-based advancement are undermined in countries and regions that are politically destabilised, plagued by civil and human rights violations and conflict ridden. Many African countries have fared badly on all counts and are far from being alone in this regard. Failures of governance, corruption, repression and rights violations are widely reported. In the first five decades of the 'development era', 1945-1995, and in sub-Saharan Africa alone, there were 39 major armed conflicts ${ }^{1}$ (Hewitt 1997:112). The continent as a whole accounted for 15 major armed conflicts in 1996, a number which reduced to nine in 2011 (Project Ploughshares $1995,2011)$, but several have restarted or broken out since. In North Africa from 2010, civil strife and armed actions are

1.Conflicts with deaths from armed violence exceeding 1000 persons associated with the 'Arab Spring' and irregular terrorism related to religious and ethnic divisions continues to be widespread. Conflict not only jeopardises public safety and uproots populations, it encourages an aggressive, militarised response to disasters.

The contradictions are underscored by two conclusions from an organisation founded, at least, with positive goals for Africa: the Africa Governance Initiative (AGI). These state that, on the one hand, '... from 2003 to 2008, the continent sustained average annual growth rates of $6 \%$. Foreign investment and exports quadrupled ...' (AGI 2011:3). On the other, however, '... [the majority of] Africans have yet to benefit from recent economic success ... [the countries of] sub-Saharan Africa ... will not achieve any of the Millennium Development Goals on time ...' (AGI 2011:3, emphasis added).

Other arguments, however, suggest 'development' itself has been a trap. How else do exponentially increased exports, imports and investments fail to support equivalent improvement in livelihoods and poverty reduction? The modern global development movement can be traced to the founding of the International Bank for Reconstruction and Development in 1944 and its mandate of December 1945, or to President Truman's 'development era' speech of 1947 (Arndt 1989). There was an initial link to disasters, in that 'reconstruction' referred to rebuilding after World War Two and appeared to be an amazing success in Europe and some East Asian countries. The purpose was then increasingly defined as supporting 'less developed' countries and especially ridding the world of poverty. As noted, this has been rewarded with remarkable rates of growth in some key economic indicators. The contradictions noted, however, turn on a rather different set of realties (Table 2).

It is important to identify conditions that are more likely to explain why the enormous export of key commodities and high value items - tropical hardwoods, cacao, gold and diamonds amongst others - are not matched by uplift in the countries concerned. Of special note in the climate change era is how this applies to African oil production. Major oil exporters in this region are Nigeria, Algeria, Angola, the Republic of Congo and Gabon, all of which have been

TABLE 1: Concerns and trends of the past two decades that undermine development in developing countries, or show its failures.

\begin{tabular}{|c|c|}
\hline Condition & Assessment $\dagger$ \\
\hline 1. Poverty & Percentages for the most impoverished have improved in most countries, but actual numbers living in poverty are greater than ever. \\
\hline 2. Services & Basic public services for safe water, health care, children and the elderly, information and outreach, remain widely unavailable. \\
\hline 3. Education & $\begin{array}{l}\text { There has been conspicuous growth, but education is compromised by underinvestment, lack of facilities, 'dead end' learning and under- } \\
\text { qualified or under-paid teachers. Many areas also still suffering serious impediments by gender, ethnicity and class. }\end{array}$ \\
\hline 4. Unemployment & Unemployment and underemployment are high, disastrously so for young persons. \\
\hline 5. National debt & Indebtedness and austerity programmes to repay debt remain huge and hit the poorest most. \\
\hline 6. Urbanisation & $\begin{array}{l}\text { Rapid urbanisation is associated with many adverse outcomes, notably growing extent of slums, unsafe buildings, destitution, intensified } \\
\text { class conflicts, crime and incarceration. }\end{array}$ \\
\hline 7. Displacement and migrant labour & $\begin{array}{l}\text { The numbers of migrants and displaced persons expand annually and, as a percentage of population, are largest in sub-Saharan Africa. } \\
\text { They usually come from, and must reside in, the most vulnerable places and communities. }\end{array}$ \\
\hline 8. Crime and conflict & Crime, drugs, human and other trafficking, corruption and armed conflict, are widespread threats to improvement and safety on all levels. \\
\hline
\end{tabular}

Source: Davis (2006); Karuri-Sebina et al. (2012); United Nations $(2011,2012)$. For more information on these sources, please see the reference list for the article Hewitt, K., 2013, 'Disasters in "development" contexts: Contradictions and options for a preventive approach', Jàmbá: Journal of Disaster Risk Studies 5(2), Art. \#91, 8 pages. http://dx.doi.org/10.4102/jamba.v5i2.91

$\dagger$, The United Nations Millennium Development Report for 2012 was more positive and the most optimistic to date. It still highlights major unresolved problems and a better performance on percentages than actual numbers. The full impact of the global financial crisis on lending and debt was not yet in evidence. 
important suppliers to the USA and various European countries for decades. If the fraction they receive of total oil wealth generated is small, those revenues still look huge for local economies, far more than anything from development aid. Yet, the same regional economies have failed to substantially improve, diversify, or reward the majority of their populations. In exchange for helping global greenhouse gas emissions, said to drive climate changes likely to have particularly adverse impacts on their populations, they still have high numbers living in poverty, in several cases $80 \%-$ $90 \%$ of national populations (Egbo et al. 2012; Shaxson 2007).

In sum, the contradictory picture for 'development' sounds a lot like that of DRR. What happens when they collide?

\section{Contradictions regarding the combined effect of disasters and development}

... so often ... disaster risk reduction falls in the cracks between development planning and disaster response ... (UNDP 2004)

A third set of contradictions are associated, in part, with how disasters are viewed as originating in dangerous agents outside society, such as flood and fire, or as unscheduled events or Acts of God (Hewitt 1983a, 2012). This helps explain how the two can be treated as separate or quite different issues. It is as though the Titanic sinking was only a result of hitting the iceberg, or the Fukushima nuclear disaster only a result of the tsunami. The perspective of social vulnerability differs sharply from such views. Rather than separating the two, it finds that processes commonly discussed as 'development' are integral to whether and how people are at risk from dangerous forces (Pelling 2003b; Wisner et al. 2004). The origins of disaster, and responsibility for it, are seen as closely dependent on everyday life and development.

Few will doubt that economic and social uplift can contribute to all the conditions and options that reduce vulnerability, or improve social security and response capacities. Equally, development projects may not bring such benefits. Disasters are certainly associated with communities suffering lack of development. They are also linked to the style and direction of development. Safety outcomes are rarely uniform across the communities involved. Projects alter or redistribute risks. In fact, there are tens of millions of persons in DCs who have lost their livelihoods, been uprooted and driven into urban slums, or entered the huge armies of migrant labour, thanks to development projects. The same people often show up as disaster victims (Middleton \& O'Keefe 1998; Penz et al. 2011). Not a few projects have led to calamities through carelessness, poor planning, arrogance, or indifference (Scott 1998).

Development programmes may also divert investment, resources, or attention away from critical risks. Commercial agriculture can improve gross food production, whilst creating food insecurity and malnutrition, as export crops or natural fibres replace local food crops. Rural people who formerly tilled the land are displaced by mechanised, commercial agriculture to less familiar, more risky areas, sites, or jobs. Developments can undermine pre-existing capacities and resilience, or limit adaptive options. Finally, otherwise fine development plans may fail to even consider protections for more vulnerable sectors, or against rare environmental extremes.

Conversely, if not addressed, disaster risks can stall and undermine development. Obviously, disasters threaten development projects (World Bank \& IEG 2006). One concern is where development funds are diverted to disaster relief and reconstruction (Van Niekerk 2008). Indeed, it is challenging to find that disaster losses in many years exceed development funds to DCs, if not their total debt load or their annual debt repayments (Wisner et al. 2004:64). However, disaster reconstruction funds may also be diverted to development priorities at the expense of recovery and risk reduction for the affected communities. Disaster assistance commonly follows pre-existing economic ties and geostrategic interests. This facilitates turning it into an opportunity for donor enterprises, as well as those in recipient countries, encouraging the diversion of funds away from DRR priorities. There are strong indications of just such a diversion in Haiti since the 2010 earthquake (Farmer 2011; UNOSE 2012).

Part of the problem is how so many mainstream disaster and development studies shy away from discussing, let

TABLE 2: Countervailing features and conditions of 'development' tending to disadvantage developing countries.

\begin{tabular}{ll}
\hline Element & Assessment \\
\hline 1 & $\begin{array}{l}\text { There is always more development in the wealthiest nations and enclaves, requiring developing countries (DCs) mainly to play a desperate game of 'catch up' } \\
\text { and debt. }\end{array}$ \\
\hline 3 & $\begin{array}{l}\text { Most development in DCs favours the already wealthiest national and global actors and usually brings them the largest financial and security rewards. } \\
\text { A large fraction of all assistance goes back to purchase expert systems and technology and to well-placed companies, outside DCs, usually from the 'donor' } \\
\text { countries themselves. }\end{array}$ \\
\hline 5 & $\begin{array}{l}\text { Development initiatives, plans and oversight are dominated by organisations based in regional, national and, especially, international metropoles. } \\
\text { sevelopment agencies and professionals are rarely expected to be proficient in the cultural, historical and political conditions in the places they supposedly } \\
\text { and centres in wealthy countries. }\end{array}$ \\
\hline 6 & $\begin{array}{l}\text { Preoccupations in 'advanced' countries drive most social and research initiatives, from birth control to global climate change. } \\
\text { The pace and commitment to modern innovation in the wealthiest nations allows them to keep moving the 'goal posts' and priorities that DCs are supposed to }\end{array}$ \\
\hline
\end{tabular}

Source: Brohman (1996); Haddad (2012); Glazebrook (2013); Kim et al. (2000); Rahnema \& Bawtree (2000). For more information on these sources, please see the reference list for the article Hewitt, K., 2013, 'Disasters in "development" contexts: Contradictions and options for a preventive approach', Jàmbá: Journal of Disaster Risk Studies 5(2), Art. \#91, 8 pages. http://dx.doi. org/10.4102/jamba.v5i2.91 
alone admitting, a political dimension. There is no sound basis for doing this. It is one thing to try to avoid ideological or, say, Eurocentric bias - if perhaps rare in practice; yet, quite another to suggest that political power and decisions are not involved in disaster and economic strategies. Hannigan (2012) takes the opposite view. He traces the sorts of contradictions outlined here to a failure to address political dimensions. He pulls together a range of topics suggesting that the international development and disasters communities rarely see eye-to-eye.

\section{When solutions become the problem}

Two global problem areas have assumed special prominence during the first decade of the ACDS's work: climate change and the financial crisis since 2008. Both seem likely to continue and grow worse in the next decade. In some respects, other than wars, they are the foremost disasters of record in the new millennium. For those of us from North America, not a day goes by without further twists, revelations and threats and a lack of consensus on anything except that there are these two great crises. Creating an adequate profile of them is beyond the scope of this paper; however, it must be recognised how both crises turn the grand solutions of the development era on their head. Arguably they have become the problem.

For 60 years, development has been seen primarily as the promise of the most fully urban-industrial and consumer economies and the donors, expertise and organisations based in them. DCs have been inspired or obliged to look to them not merely for investment and advice, but the more promising styles of modernisation and acceptable social uplift. The same societies have been the main proponents of modernised emergency and disaster management. The language of DRR in almost all countries comes from them and African countries are urged to utilise their knowledge base, tools, resources and expertise as the main promise of DRR.

However, developed country wealth has been built around massive use of fossil fuels and the internal combustion engine. In turn, these underpin industrialisation and mechanisation, superior armaments and fire power, automotive power, electrification and electronics and have required massive extraction and processing of mineral, biological and hydrological resources. These systems drive unprecedented movement of goods, people, information, wastes and contaminants. They are much the greatest sources of anthropogenic greenhouse gases and most other serious threats to the biosphere and human health. Contrary to a common perception, wealthier nations and enclaves vastly outstrip the 'ecological footprint' of the poorest four to five billion folk, commonly featured in 'over-population' arguments. Meanwhile, those more traditional societies still exist, based on support systems that have proved sustainable for millennia, whether romanticised or demeaned, and are being undermined, replaced, or destroyed in the name of development (Brohman 1996; Davis 2006; Kim et al. 2000). Thus do the developed nations define the style of modernisation offered to solve Africa's economic, social and safety futures.

In this sense, global climate change and the financial crisis present the same image and dilemma. Both originate, overwhelmingly, in the wealthiest institutions and groups, mainly as a consequence of activities promoted and underwritten by the G7 countries. The present climate change problem is 'man-made' and originates largely in these countries, or global industrial and resource extraction activities driven by them. Coal-burning factories in China and India, for example, may be significant and growing contributors; yet, their products go to, generate the most wealth from, and depend on markets in the developed world if, also, on increasingly large resource extraction in DCs. They are closely intertwined with global financial, trade and retail organisations.

The anthropogenic role in climate change, and a widely promoted strategy of 'adaptation' to it, highlight the contradictions. One can accept that, ultimately, humans must deal with threats to survival and social continuity by adapting. However, there is only one set of adaptations with any prospect of reversing global warming, of mitigating or avoiding climate-related threats: immediate reductions in fossil fuel production and consumption. However, these have yet to occur in the heartlands and institutions of urbanindustrial, mechanised modernisation. Instead, the problem grows worse, especially because those states and corporate leaders with the greatest power of decision in such matters refuse to act. They invest mainly in the opposite: anything to generate growth of oil extraction, motor car sales and related activities.

Meanwhile, the disasters community is being urged to focus on, '... impacts - increased drought and flooding, sea level rise, and dysfunctional [sic] and unpredictable weather patterns ...' (Hannigan 2012:79). The talk is of 'hot spots' defined by natural agents thought to be especially sensitive to climate change and, for unclear reasons, largely or wholly in DCs (World Bank 2006, 2012). In this way, a fundamentally 'man-made' source of danger is being treated as a classic natural hazards problem. Indeed, it signals a return to the language of an 'agent-specific' determinism of risk, rather than focusing on the actual, unnatural source of the calamity (Gilbert 1998; O'Keefe et al. 1976). Moreover, it is not just that:

Climate change is expected to hit developing countries the hardest. At stake are recent gains in the fight against poverty, hunger and disease, and the lives and livelihoods of billions of people in developing countries. (World Bank 2012)

More to the point, these folks are the ones who are being expected to 'adapt'.

This highlights the futility of a natural hazards-based approach. It is laudable to underline the plight of people in low-lying ocean islands and coastal cities, or farmers in 
drought-prone tropical regions. However, even if funding were available for every adaptation proposed around the shores and on the islands of the Indian Ocean and for Oceania, or the Sahel of Africa, these would still be temporary solutions, postponing worse risk in future. The coastlines and low-lying islands will be increasingly submerged, storm surges will move much further inland, floods and droughts will intensify.

The global financial crisis involves similar back-to-front causal and geographical arguments. The problem originates in the financial systems and actions of the wealthiest countries, institutions and elites. Responses thus far, ostensibly to stabilise global finance, save the banking system and bring greater care over debt and investment, have been at the cost of a massive redistribution of wealth from the less to the more wealthy. It has resulted in greater unemployment, homelessness, reduced social protections, economic downturn and a withholding or diverting funds from development. The needs and uplift of those who make up the bulk of all disaster victims are, at best, on hold.

Herein lie the, largely unacknowledged, great challenges for the whole development and disasters nexus. Unless you are in denial, you will find that the conventional solutions for development and for disaster management have become the main obstructions or threats to them. And the central question then becomes: does this not lie at the base of the contradictions outlined? In both areas, for net improvements in living conditions and safety around the world, development 'as usual' is not an option; growth in the conventional material and financial bases of modern urban-industrial progress is the gravest danger for most people. Rather, arguments for finding alternatives are strengthened.

\section{Conclusion: Precautionary and preventive approaches}

Media coverage, even many experts, leave the impression that environmental disasters are caused by extreme, unstoppable forces, earthquake or storm, fire or explosion. The damages seem unavoidable, survival a matter of luck or outside intervention. Yet, there is a considerable body of research and some leading agencies that support a different view (Bankoff et al. 2004; Hewitt 2012; IFRCRCS 2004; UNDP 2004). This emerges when you look beyond the immediate shocking scenes, or gross casualty and dollar estimates, to just where, how and, especially, to whom damages happen. They are socially specific and, if storm and flood are impersonal, they arise from social rather than environmental forces.

Again, detailed investigations and reconstructions of the conditions that lead to disasters reveal that much or all losses could have been avoided. Most could have been prevented or greatly reduced with available, affordable means, often by standards recommended if not mandated, but not enforced (Gonzalez, Romano \& Salamanca 2007; Kunreuther \& MichelKerjan 2010; McLean \& Johnes 2000; Ozerdem \& Jacoby 2006; Turner 1978; Wisner et al. 2004). It is not that there are no natural forces beyond the capacity of any human measures to withstand or prevent. However, they turn out to apply in very few recent disasters or in only a few places within them. People are at risk from environmental hazards primarily through conditions in which society intervenes massively, partly during and after emergencies but, most critically, before them. Again and again, damage and mortality profiles show that pre-existing vulnerabilities and absent protections decide who lives and dies, what is destroyed and what survives. This applies to people's exposure, the vulnerability of their bodies, homes and livelihoods, available or absent protections and response capacities. This is the core of causal relations between disaster and development.

In such terms, there are just two broad approaches to disaster, two critical groups. For one, disaster is, at best, a security problem and management opportunity. This usually comes with a view of the losses and victims as unfortunate but inevitable; it is ultimately about Mother Nature or Acts of God, uncertainty and unscheduled events. Some are lucky, others unlucky. Just get on with it; stay with 'professional' disaster management and pursue the fight to control Nature (cf. Gilbert 1998; Steinberg 2000).

In the other view, the focus is on those at risk, especially the unnecessary trauma and misery disaster brings. If, as vulnerability research shows, most losses could be avoided or diminished, then that should be the focus of our efforts. If there are ways to prevent and avoid harm that is what matters and, where not possible, means to minimise and alleviate suffering and loss. These are only found by looking outside disasters to the pre-conditions of vulnerability and protections. Development strategies can and should pursue this and be assessed by how well they do so. Hence, the emphasis is on prevention wherever possible and precautionary measures where not. For the latter, the imperative to 'do no harm' means scrupulous concern to forego and replace projects whose safety consequences are uncertain or unfair. Development must be constrained by risk avoidance and against redistribution of risks where some may benefit, but others are worse off. This is where a social vulnerability approach shows and requires development and disaster to be integrally related.

\section{Acknowledgements}

I thank members of the ACDS and Farida Azhar-Hewitt for critiquing and making helpful suggestions on the text. This is very much a 'think piece' rather than a report on research and I need to thank colleagues whose work and suggestions have helped in developing these ideas; notably over the years: Ian Burton, Jonathan Crush, Ian Davis, Allan Lavell, Manjari Mehta, George Morren, Anthony Oliver-Smith, Ted Steinberg and Ben Wisner.

\section{Competing interests}

The author declares that he has no financial or personal relationships which may have inappropriately influenced him in writing this article. 


\section{References}

Africa Governance Initiative, 2011, Commission for Africa report 2010 - Still ou common interest, AGI, London.

Arndt, H.W., 1989, Economic development: The history of an idea, University of Chicago Press, Chicago.

Asian Development Bank, 2013, Investing in resilience: Ensuring disaster-resistan future, ADB, Manila.

Baez, J.E. \& Santos, I.V., 2008, On shaky ground: The effects of earthquakes on household income and poverty, UNDP Regional Bureau for Latin America and the Caribbean, New York.

Bankoff, G., Frerks, G. \& Hihorst, D. (eds.), 2004, Mapping vulnerability: Disasters, development and people, Earthscan, London.

Brohman, J., 1996, Popular development: Rethinking the theory and practice of development, Blackwell, Oxford.

Calhoun, C., 2004, 'A world of emergencies: Fear, intervention, and the limits of cosmopolitan order', The Canadian Review of Sociology and Anthropology 41 cosmopolitan order', The Canadian Review of Sociology and Anth
373-395. http://dx.doi.org/10.1111/j.1755-618X.2004.tb00783.x

Coelho, J.P.B., 2007, 'The state, the community and natural calamities in rura Mozambique', in B. de S. Santos (ed.), Another knowledge is possible: Beyond northern epistemologies, pp. 219-243, Verso, London. PMid:18163975

Davis, M., 2006, Planet of slums, Verso, New York.

Egbo, O., Nwakoby, I., Onwumere, J. \& Uche, C., 2012, 'Security votes in Nigeria: Disguised stealing from the public purse', African Affairs 111(455), 597-614. http://dx.doi.org/10.1093/afraf/ads060

Ekine, S., 2013, 'Hiati is open for exploitation. Humanitarian pillage and racism continue', Pambazuka News 614, viewed 17 April 2013, from http://pambazuka. org/en/category/features/86048

Enarson, E. \& Morrow, B.H., 1998, The gendered terrain of disaster: Through women's eyes, Praeger, Westport.

Farmer, P., 2011, Haiti after the earthquake, Public Affairs, New York.

Fernandez, M.A. (ed.), 1999, Cities at risk: Environmental degradation, urban risks and disaster in Latin America, The Network for Social Studies on Disaster, Lima.

Food and Agricultural Organization of the United Nations, 2008, 'Climate change and disaster risk management, technical background document', $\mathrm{HLC} / 08 / \mathrm{BAK} / 5$, presented at the Climate Change, Energy and Food Conference, Rome, 03-05 June.

Fordham, M., 2003, 'Gender, development and disaster: The necessity for integration', in M. Pelling (ed.), Natural disasters and development in a globalizing world, $\mathrm{pp}$ 57-74, Routledge, London.

Gilbert, C., 1998, 'Studying disasters: Changes in the main conceptual tools', in E. Quarantelli (ed.), What is a disaster? Perspectives on the question, pp. 11-18, Routledge, New York.

Glazebrook, D., 2013, 'The West's war against African development continues' Pambazuka News 617, viewed 17 April 2013, from http://pambazuka.org/en/ category/features/86332

Global Financial Integrity, 2008, Illicit financial flows from developing countries: 20022006, GFI, Washington, DC

Global Financial Integrity, 2012, Illicit financial flows from Africa: Hidden resource for development, $\mathrm{GFI}$, Washington, DC

Gonzalez, L., Romano, L. \& Salamanca, L., 2007, 'Risks and disasters in El Salvador: Economic, environmental and social aspects', in W.I. Rose, J.J. Bommer, D.L. Lopez, M.J. Carr \& J.J. Major (eds.), Natural hazards in El Salvador, Special paper 375, pp 461-470, Geological Society of America, Boulder.

GRAIN, 2012, Squeezing Africa dry: Behind every land grab is a water grab, viewed 17 April 2013, from http://www.grain.org/article/entries/4516

Haddad, L., 2012, 'Five assumptions of dominant thinking in international development', Development 55(1), 34-44. http://dx.doi.org/10.1057/ dev.2011.106

Hannigan, J., 2012, Disasters without borders, Polity Press, London.

Hewitt, K., 1983a, 'The idea of calamity in a technocratic age', in K. Hewitt (ed.), Interpretations of calamity from the viewpoint of human ecology, pp. 3-32, Allen and Unwin, London.

Hewitt, K. (ed.), 1983b, Interpretations of calamity from the viewpoint of human ecology, Allen and Unwin, London.

Hewitt, K., 1997, Regions of risk: Hazards, vulnerability and disasters, Longman/ Pearson, London.

Hewitt, K., 2007, 'Preventable disasters: Addressing social vulnerability, Institutional risk and civil ethics', Geographische Rundschau, International Edition 3(1), 43-45.

Hewitt, K., 2012, 'Environmental disasters in social context: Toward a preventive and precautionary approach', Natural Hazards 52. http://dx.doi.org/10.1007/s11069012-0205-6

International Federation of Red Cross and Red Crescent Societies, 2004, World disasters report: Focus on community resilience, IFRCRCS, Geneva.

Karuri-Sebina, G., Sall, A., Maharakh, R. \& Segobye, A., 2012, 'Fictions, factors and futures: Reflections on Africa's “impressive growth"', Development 55(4), 491496. http://dx.doi.org/10.1057/dev.2012.75

Kern, W. (ed.), 2010, The economics of natural and unnatural disasters, W.E. Upjohn Institute, Kallamazoo.

Kim, J.Y., Millen, J.V., Irwin, A. \& Gershman, J. (eds.), 2000, 'Dying for growth: Global inequality and the health of the poor', Common Courage Press, Monroe.

Kunreuther, H.C. \& Michel-Kerjan, E.O., 2010, 'Market and government failure in insuring and mitigating natural catastrophes: How long-term contracts can help', in W. Kern (ed.), The economics of natural and unnatural disasters, pp. 9-38, W.E. Upjohn Institute, Kallamazoo.
Lavell, A. (ed.), 1994, Viviendo en Riesgo: Comunidades Vulnerables y Prevencion de Desastres en America Latina [Living at risk: Vulnerable communities and disaster prevention in Latin America], LA RED/FLACSO, Bogota.

McLean, I. \& Johnes, M., 2000, Aberfan: Disasters and government, Welsh Academic Press, Cardiff.

Middleton, N. \& O'Keefe, P., 1998, Disaster and development: The politics of humanitarian aid, Pluto Press, London.

Mitchell, J.K., 1999, Crucibles of hazard: Mega-cities and disaster in transition, UNU Press, Tokyo.

O'Keefe, P., Westgate, K. \& Wisner, B., 1976, 'Taking the naturalness out of disaster', Nature 260(April), 566-567. http://dx.doi.org/10.1038/260566a0

Oliver-Smith, A.S., 1986, The martyred city: Death and rebirth in the Andes, 2nd edn. Waveland Press, Prospect Heights.

Oliver-Smith, A.S. \& Hoffman, S.M. (eds.), 2003, The angry earth, Routledge, New York.

Olowu, D., 2010, 'The Hyogo framework for action and its implications for disaster management and reduction in Africa', JAMBA: Journal of Disaster Risk Studies 3(1), 303-320.

Ozerdem, A. \& Jacoby, T., 2006, Disaster management and civil society: Earthquake relief in Japan, Turkey and India, I.B. Tuaris, London.

Pelling, M., 2003a, The vulnerability of cities: Natural disasters and social resilience, Earthscan, London.

Pelling, M. (ed.), 2003b, Natural disasters and development in a globalizing world, Routledge, London.

Penz, P., Drydyk, J. \& Bose, P.S., 2011, Displacement by development: Ethics, rights and responsibilities, Cambridge University Press, Cambridge. http://dx.doi. org/10.1017/СBO9780511973499

Project Ploughshares, 1995, Armed conflicts reports, 1995, Institute of Peace and Conflict Studies, University of Waterloo, Waterloo.

Project Ploughshares, 2011, Ploughshares annual report, 2011, Project Ploughshares, Waterloo.

Rahnema, M. \& Bawtree, V. (eds.), 2000, The post-development reader, David Philip, Cape Town. PMid:10947083

Satterthwaite, D., 1991, 'Urban and industrial environmental policy and management', in J.T. Winpenny (ed.), Development research: The environmental challenge, pp. 119-136, Overseas Development Institute, London.

Scott, J.C., 1998, Seeing like a state. How certain schemes to improve the human condition have failed, Yale University Press, Newhaven.

Shaxson, N., 2007, Poisoned wells: The dirty politics of African oil, Palgrave-Macmillan, New York. PMid:17612325

Steinberg, T., 2000, Acts of God: The unnatural history of natural disaster in America Oxford University Press, New York.

Swiss Re, 2012, Global insurance review 2012 and outlook 2013/14, Swiss Re, Zurich.

Turner, B.A., 1978, Man-made disasters, Wykeham Publications, London.

United Nations, 2011, Millennium development goal 8: The global partnership for development: Time to deliver. MDG Gap Task Force report, 2011, UN, New York.

United Nations, 2012, Millennium development goal 8: The global partnership for development: Making rhetoric a reality. MDG Gap Task Force report, 2012, UN, New York.

United Nations Development Programme, 2004, A global report, reducing disaster risk: A challenge for Development, UNDP Bureau of Crisis Prevention and Management, New York.

United Nations Office for Disaster Risk Reduction, 2002, Living with risk: A globa review of disaster reduction initiatives, UNISDR, Geneva.

United Nations Office for Disaster Risk Reduction, 2006, Hyogo framework for action 2005-2015: Building the resilience of nations and communities to disasters: Fina 2005-2015: Building the resilience of nations and communities to disasters: Final
report of the World Conference on disaster reduction (A/CONF.206/6), UNISDR, report of thi
Geneva.

United Nations Office for Disaster Risk Reduction, 2012, Impacts of disasters since the 1992 Rio de Janeiro Earth Summit, UNISDR, Geneva, viewed 17 April 2013, from http://www.unisdr.org/files/27162_infographic.pdf

United Nations Office of the Special Envoy for Haiti, 2012, Can more aid stay in Hait and other fragile settings? How local investment can strengthen governments and economies, UNOSE, New York.

United Nations \& World Bank, 2010, Natural hazards, unnatural disasters: The economics of effective prevention, UN and World Bank, Washington, DC.

Van Niekerk, D., 2008, 'From disaster relief to disaster risk reduction: A consideration of the evolving international relief mechanism', TD: The Journal for Transdisciplinary Research in Southern Africa 4(2), 355-376.

White, G.F., 1969, Choice of adjustments to floods, Department of Geography research paper 93, University of Chicago Press, Chicago.

Wisner, B., Blaikie, P., Cannon, T. \& Davis, I., 2004, At risk: Natural hazards, people's vulnerability and disasters, 2 nd edn., Routledge, London.

World Bank, 2001, Gujarat earthquake recovery program: Assessment report, World Bank and ADB, Ahmedabad.

World Bank, 2012, Climate change and the World Bank: Context, viewed 17 April 2013, from http://climatechange.worldbank.org/overview

World Bank \& Independent Evaluation Group, 2006, Hazards of nature, risks to development. An IEG evaluation of World Bank assistance for natural disasters, World Bank and IEG, Washington, DC

World Commission on Environment and Development, 1987, Our common future, Oxford University Press, Oxford. 